\title{
Methodology and results of the investigation monitoring in the Russian NPP vicinity
}

\author{
N. K. Shandala, N. Ya. Novikova, S. M. Kiselev, D. V. Isaev, \\ V. A. Seregin, E. G. Metlyaev \& Yu. A. Shchagin \\ Burnasyan Federal Medical Biophysical Centre, Russia
}

\begin{abstract}
Investigation monitoring in the vicinity of nuclear power plants (NPP) includes radiation hygienic monitoring and population health monitoring. Radiation hygienic monitoring is the system of the comprehensive and dynamic surveillance including the long-term continuous control of radiation hygienic situation parameters and doses of residents in the near-by areas of NPP. In the reference points of the NPP surveillance area and in the comparison area, the specialized rules are elaborated. These rules include the types of environmental media, scope and periodicity of sampling, methodological and technical requirements, etc. Two approaches are used for population health assessment: epidemiological and cohort. Medical demography characteristics are based upon indices of the birth rate, general malignant neoplasm mortality, and infant and childhood mortality. Morbidity is used as quantitative and qualitative index of the population health. The radiation hygienic situation in NPP surveillance areas is generally satisfactory and stable. The individual population risk for all radiation sources in surveillance areas of three examined NPPs is $(2.5-3.1) \cdot 10^{-4}$ cases per year. The individual risk related to the NPP operation is $0.4 \cdot 10^{-12}$ (Volgodonsk NPP) to $3.2 \cdot 10^{-8}$ (Novovoronezh NPP) cases per year. Thus, this risk is hundreds and even million times lower if compared to unconditional acceptable risk $-1 \cdot 10^{-6}$. The assessment of the health baseline as well as in the comparison areas was elaborated applying data of state medical statistics within more than ten years. The peculiar attention was attracted to the malignant neoplasm morbidity, their incidence rate and dynamics. The developed comprehensive investigation monitoring in the NPP vicinity should be the necessary part of the nationwide system of the public radiation protection regulation under nuclear renaissance, because it provides the opportunity to get
\end{abstract}


the modern objective assessment of the NPP impact in the environment and population health.

Keywords: NPP, radiation hygienic monitoring, population health monitoring, surveillance area, environmental objects, exposure doses, radiation risk, morbidity.

\section{Introduction}

The basic social requirement for the atomic power is the provision of convincible evidences of the safety warrantees of both the plant operation personnel and residents of the NPP affected area. Since the USSR atomic industry start-up, the Burnasyan Federal Medical Biophysical Centre (before 2008 - Institute of Biophysics) of the Federal Medical Biological Agency of Russian Federation was the leading institution responsible for the medical issues of the industry. One of basic activities of the Burnasyan Federal Medical Biophysical Centre is the scientific support of the radiation protection of the public.

The analysis of medical effects of the Chernobyl accident has obviously demonstrated the high importance of the establishing so-called "zero" baseline of the population health. Such information is necessary to evaluate the possible medical effects of many year operation of atomic facilities and to clarify the scale of the health impact. Such assessments require vast comprehensive hygienic studies within the long period of time. Thus, the necessity to organize the rigorous social hygienic monitoring (SHM) in the NPP vicinity is occurred, which is the system of state surveillance, analysis, assessment, and prognosis of the population health and habituated environment as well as the correlation of the population health versus the habituated environment factor exposure. According to the Russian Federation Law on Sanitary and epidemiological wellbeing of the population, SHM is the major mechanism to regulate this wellbeing. The SHM implementation is of specific significance, taking into account special document regulates this work and attributes it not only to sanitary and epidemiological authorities and institutions, but also to other ministries and agencies [1]. Present SHM system presumes the development of the unified system of collection, management, and assessment of the information regarding the environmental contamination and population health indices.

The purpose of the present paper is to describe methodology and current status of SHM results obtained in the NPP vicinity. SHM includes radiation hygienic monitoring and population health monitoring.

\section{Ideology and methodology of the research}

The main stages of SHM in the NPP vicinity are as follows:

- Conducting of background "zero" examination of public health and radiation hygienic situation before the NPP start-up;

- Dynamic monitoring of important parameters of public health and hygienic parameters (including radiation factor) during the whole NPP operation period; 
- Comparison of observed changes of public health and environment against "background" values;

- Observation of changes of public health within 5-10 years after decommissioning NPP or reactor units.

Following eight SHM directions are included for the NPP vicinity:

1. Radiation hygienic situation specifications and population doses

2. Medical demography features of the populations

3. Population morbidity analysis

4. Reproductive health status

5. Endemic diseases

6. Children health status

7. Societal psycho-physiological status of the population and mass media relations

8. Monitoring data bank development.

The scientific ideology of the this research is investigation radiation hygienic monitoring (RHM), which is the system of the comprehensive and dynamic surveillance including the long-term continuous control of radiation hygienic situation parameters and doses of residents in the near-by areas of NPP and other radiation facilities of the first category [2].

The obvious question on the differences between research RHM and radiation control elaborated by different agencies and organizations is occurred. It is clear that radiation situation monitoring in the NPP surveillance area is elaborated by the NPP operator and designer, hydrometeorology service, and sanitary and epidemiological surveillance service. Results of such control attributed to the agency responsibility as well as elaborated under the radiation hygienic certification of territories have some disadvantages. These disadvantages include the rare application of radiochemical techniques, low periodicity of examinations, insignificant number of comparison points, and, in some cases, the absence of the comparison area and significant change of the list of objects subjected to the control. Finally, the radiation factor is not considered together with other non-radiation environmental factors affecting the human and the ranking of these factors is not provided. Unfortunately, low levels of radiation hygienic parameters are not recorded in practice. The indicated disadvantages of the practical radiation monitoring can be corrected by the implementation the detailed investigation RHM.

To elaborate RHM in the reference points of the NPP surveillance area and in the comparison area, the specialized rules are elaborated. These rules include the types of environmental objects, scope and periodicity of sampling, methodological and technical requirements, and inter-relations of interested parties. Table 1 provides a number of aspects of elaborated RHM rules on the sampling and examined parameters of the radiation hygienic situation in the NPP vicinity. RHM rules (environment section) presume the usage of NPP surveillance network data obtained by State Hydrometeorology Committee and Automated System of Radiation Situation Control as well as the original own data [3]. 
Table 1: $\quad$ Periodicity of sampling and examined parameters in the control points of the NPP surveillance area (routine operation) and in the comparison area.

\begin{tabular}{|c|c|c|c|}
\hline $\begin{array}{l}\text { Supervision } \\
\text { object }\end{array}$ & $\begin{array}{l}\text { Periodicity of } \\
\text { information } \\
\text { receipt }\end{array}$ & Parameters & \begin{tabular}{|l|} 
Value \\
dimensionality \\
to be measured \\
\end{tabular} \\
\hline \multicolumn{4}{|c|}{ Environment } \\
\hline $\begin{array}{l}\text { Gamma } \\
\text { background in } \\
\text { the area }\end{array}$ & $\begin{array}{l}\text { Random } \\
\text { inspection } \\
\text { (weekly) }\end{array}$ & $\begin{array}{l}\text { Exposure dose rate of } \\
\text { external } \gamma \text { radiation in } \\
\text { the area } \\
\text { Effective dose rate of } \\
\text { external } \gamma \text { radiation }\end{array}$ & $\begin{array}{l}\mu \mathrm{R} / \mathrm{h} \\
\mathrm{mSv} / \mathrm{y}\end{array}$ \\
\hline $\begin{array}{l}\text { Atmospheric air } \\
\text { (aerosol content } \\
\text { in surface air) }\end{array}$ & Daily, monthly & $\begin{array}{l}\text { ß-radioactivity, }{ }^{90} \mathrm{Sr} \text {, } \\
{ }^{137} \mathrm{Cs},{ }^{134} \mathrm{Cs} \text {. Content } \\
\text { of inert radioactive } \\
\text { gases, }{ }^{131} \mathrm{I},{ }^{60} \mathrm{Co}\end{array}$ & $\mathrm{Bq} / \mathrm{m}^{3}$ \\
\hline $\begin{array}{l}\text { Density of } \\
\text { radioactive } \\
\text { fallout }\end{array}$ & Monthly & $\begin{array}{l}\text { Total ß-radioactivity, } \\
{ }^{90} \mathrm{Sr},{ }^{137} \mathrm{Cs},{ }^{131} \mathrm{I}\end{array}$ & $\mathrm{Bq} / \mathrm{m}^{2} /$ month \\
\hline Soil & Annually & $\begin{array}{l}\text { Total ß-radioactivity, } \\
{ }^{90} \mathrm{Sr},{ }^{137} \mathrm{Cs},{ }^{40} \mathrm{~K}\end{array}$ & $\mathrm{~Bq} / \mathrm{kg}, \mathrm{kBq} / \mathrm{m}^{2}$ \\
\hline $\begin{array}{l}\text { Gamma grasses } \\
\text { or natural } \\
\text { growth }\end{array}$ & $\begin{array}{l}\text { Annually (during } \\
\text { period of } \\
\text { vegetation) }\end{array}$ & $\begin{array}{l}\text { Total ß-radioactivity, } \\
{ }^{90} \mathrm{Sr},{ }^{137} \mathrm{Cs},{ }^{40} \mathrm{~K},{ }^{131} \mathrm{I}\end{array}$ & $\mathrm{Bq} / \mathrm{kg}$ \\
\hline $\begin{array}{l}\text { Water of open } \\
\text { ponds including } \\
\text { water reservoir- } \\
\text { cooler }\end{array}$ & $\begin{array}{l}\text { Two times a year } \\
\text { (random } \\
\text { inspection) }\end{array}$ & $\begin{array}{l}\text { Total } \alpha \text { - and } \beta- \\
\text { radioactivity, }{ }^{90} \mathrm{Sr}, \\
{ }^{137} \mathrm{Cs} \text {. In water } \\
\text { reservoir-cooler: }{ }^{131} \mathrm{I} \text {, } \\
{ }^{60} \mathrm{Co},{ }^{90} \mathrm{Sr}\end{array}$ & $\mathrm{Bq} / \mathrm{l}$ \\
\hline $\begin{array}{l}\text { Underground } \\
\text { sources of } \\
\text { water (using } \\
\text { observation } \\
\text { wells) }\end{array}$ & $\begin{array}{l}\text { Monthly (random } \\
\text { inspection) }\end{array}$ & $\begin{array}{l}\text { Total } \alpha \text { - and } \beta- \\
\text { radioactivity, }{ }^{90} \mathrm{Sr} \text {, } \\
{ }^{137} \mathrm{Cs},{ }^{3} \mathrm{H}\end{array}$ & $\mathrm{Bq} / \mathrm{l}$ \\
\hline $\begin{array}{l}\text { Drinking water } \\
\text { (using draw } \\
\text { well and water } \\
\text { supply systems) }\end{array}$ & Quarterly & $\begin{array}{l}\text { Total } \alpha \text { - and } \beta- \\
\text { radioactivity, }{ }^{90} \mathrm{Sr} \text {, } \\
{ }^{137} \mathrm{Cs}\end{array}$ & $\mathrm{Bq} / \mathrm{kg}$ \\
\hline $\begin{array}{l}\text { Water-plants } \\
\text { and sea-floor } \\
\text { sediments of } \\
\text { open ponds }\end{array}$ & $\begin{array}{l}\text { Annually (random } \\
\text { inspection) }\end{array}$ & $\begin{array}{l}{ }^{90} \mathrm{Sr},{ }^{137} \mathrm{Cs},{ }^{40} \mathrm{~K} \text { in } \\
\text { water-plants - total } \beta- \\
\text { radioactivity }\end{array}$ & $\mathrm{Bq} / \mathrm{kg}$ \\
\hline
\end{tabular}


Table 1: Continued.

\begin{tabular}{|l|l|l|l|}
\hline Supervision object & $\begin{array}{l}\text { Periodicity of } \\
\text { information receipt }\end{array}$ & Parameters & $\begin{array}{l}\text { Value } \\
\text { dimensionality } \\
\text { to be measured }\end{array}$ \\
\hline \multicolumn{3}{|c|}{ Foodstuffs of local manufacture } \\
\hline Bread or bread flour & Annually & ${ }^{90} \mathrm{Sr},{ }^{137} \mathrm{Cs}$ & $\mathrm{Bq} / \mathrm{kg}$ \\
\hline Grain (wheat) & Annually & ${ }^{90} \mathrm{Sr},{ }^{137} \mathrm{Cs}$ & $\mathrm{Bq} / \mathrm{kg}$ \\
\hline Milk & $\begin{array}{l}\text { Two times a year } \\
\text { (in summer and in } \\
\text { winter) }\end{array}$ & ${ }^{90} \mathrm{Sr},{ }^{137} \mathrm{Cs},{ }^{131} \mathrm{I}$ & $\mathrm{Bq} / 1$ \\
\hline $\begin{array}{l}\text { Meat (pork, beef, } \\
\text { mutton) }\end{array}$ & Annually & ${ }^{90} \mathrm{Sr},{ }^{137} \mathrm{Cs}$ & $\mathrm{Bq} / \mathrm{kg}$ \\
\hline Poultry meat & Two times a year & ${ }^{90} \mathrm{Sr},{ }^{137} \mathrm{Cs}$ & $\mathrm{Bq} / \mathrm{kg}$ \\
\hline $\begin{array}{l}\text { Freshwater fish } \\
\text { (river and lake ones) }\end{array}$ & $\begin{array}{l}\text { Annually } \\
\text { Annually (during } \\
\text { Potatoes }\end{array}$ & ${ }^{90} \mathrm{Sr},{ }^{137} \mathrm{Cs}$ & $\mathrm{Bq} / \mathrm{kg}$ \\
\hline $\begin{array}{l}\text { Edible roots (beet, } \\
\text { carrot) }\end{array}$ & $\begin{array}{l}\text { Annually (during } \\
\text { harvesting) }\end{array}$ & ${ }^{137} \mathrm{Cs},{ }^{90} \mathrm{Cs}$ & $\mathrm{Bq} / \mathrm{kg}$ \\
\hline $\begin{array}{l}\text { Vegetables } \\
\text { (cucumbers, } \\
\text { tomatoes, onion, } \\
\text { cabbage) }\end{array}$ & $\begin{array}{l}\text { Annually (during } \\
\text { harvesting) }\end{array}$ & ${ }^{90} \mathrm{Sr},{ }^{137} \mathrm{Cs}$ & $\mathrm{Bq} / \mathrm{kg}$ \\
\hline $\begin{array}{l}\text { Gourds (melon, } \\
\text { water-melons) }\end{array}$ & $\begin{array}{l}\text { Annually (during } \\
\text { harvesting) }\end{array}$ & ${ }^{90} \mathrm{Sr},{ }^{137} \mathrm{Cs}$ & $\mathrm{Bq} / \mathrm{kg}$ \\
\hline $\begin{array}{l}\text { Food pot-herbs and } \\
\text { leaf vegetables }\end{array}$ & $\begin{array}{l}\text { Two times a year } \\
\text { (during period of } \\
\text { vegetation) }\end{array}$ & ${ }^{90} \mathrm{Sr},{ }^{137} \mathrm{Cs},{ }^{131} \mathrm{I}$ & $\mathrm{Bq} / \mathrm{kg}$ \\
\hline $\begin{array}{l}\text { Garden fruits and } \\
\text { berries (at places of } \\
\text { harvest) }\end{array}$ & $\begin{array}{l}\text { Annually (during } \\
\text { harvesting) }\end{array}$ & ${ }^{90} \mathrm{Sr},{ }^{137} \mathrm{Cs}$ & $\mathrm{Bq} / \mathrm{kg}$ \\
\hline
\end{tabular}

When choosing the comparison area, following circumstances should be taken into account:

a) hygienic characteristics similarity:

- soil and sub-soil type;

- plant species;

- chemical content of water in superficial reservoirs and underground waters;

- conditions of foodstuff production;

- burdens of natural and (or) global fallout radionuclides.

b) the positioning outside the radiation facility affecting area;

c) medical assistance peculiarities (number of specialized medical doctors and availability of medical equipment etc.). 
We would like to address population health monitoring, which requires the scientific justification of index selection and population health assessment criteria. These criteria should correspond to the following conditions:

- $\quad$ Applicability for the population assessment;

- Correspondence to the long-term observation tasks, namely, the simplicity, the applicability for the large number of individual examinations, reliable quantification, and objective qualitative characteristics;

- $\quad$ Future possibility for the assessment of possible NPP radiation impact in population health.

Two approaches are used for population health assessment: epidemiological approach based upon the health evaluation via medical statistics data and cohort clinical approach to include health assessments via detailed examination of critical population groups and critical body systems.

Medical demography characteristics are based upon indices of the birth rate, general malignant neoplasm mortality, infant and childhood mortality.

Morbidity is used as quantitative and qualitative index of the population health to assess the dissemination and structure of major diseases in the population of the NPP vicinity. To evaluate health status, medical statistics data are applied and dynamic indices within many years are analyzed.

The index reflecting the population health as a whole is the reproductive health. Reproductive health changes are most specific to the unfavorable factor impact in human health. Basic parameters of the reproductive health are as follows:

a) obstetric and gynecological status (rate and character of the pregnancy termination, gynecological and oncological morbidity)

b) reproduction function state (spontaneous abortions, still birth, early neonatal mortality) and newborn condition (morbidity, inherited developmental defects, etc.).

The child organism at growth and development phase is specific to the peculiar sensitivity, so the children under the radiation risk compose the population critical group. In the framework of the elaborated children health monitoring, statistical data on pediatric assistance are used as well as the detailed clinical examination results in some groups of children.

The "baseline" data on leukemia and thyroid morbidity are essential for the comprehensive assessment of NPP vicinity resident health to use these data as the reference for the following radiation exposure effects. Thyroid examinations presume endocrinologist evaluation and ultrasound imaging to obtain sizes and echo structure as well as the iodine deficiency assessment via urinalysis.

\section{Material and methods}

The investigation monitoring been implemented in a number of Russian NPPs including Kalinin, Volgodonsk and Novovoronezh NPPs. When implementing monitoring the following tasks were elaborated: 
1. The dynamic acquisition of necessary, sufficient, and confident information on controllable radiation parameters of the environment and on radionuclide burdens in foodstuff and water.

2. Investigation of the foodstuff consumption.

3. Assessment of the external and internal exposure doses in population.

4. Revealing current changes of radiation hygienic situation and prognosis of possible consequences in the population.

5. Providing the information for the managerial decision making to keep radiation doses as low as reasonably achievable.

6. Providing the information for local authorities and local centers of State Sanitary and Epidemiological Surveillance on radiation hygienic situation in the surveyed territory.

7. Forming the databases on the examined parameters.

8. Providing the information for local residents of the NPP vicinity.

More than 670 environmental and foodstuff samples in 48 settlements positioned both in the surveillance areas and in the comparison areas, in cooling ponds and other water reservoirs of the NPP vicinity was investigated (Table 2).

Table 2: The amount of investigations, which were carried out nearby NPPs.

\begin{tabular}{|c|c|c|c|c|}
\hline \multirow{2}{*}{ NPP } & Quantity & \multicolumn{3}{|c|}{ Number of proof samples } \\
\cline { 3 - 5 } & of points & Foodstuffs & $\begin{array}{c}\text { Drinking } \\
\text { water }\end{array}$ & $\begin{array}{c}\text { Other objects of } \\
\text { environment }\end{array}$ \\
\hline Volgodonsk & 22 & 270 & 26 & 24 \\
\hline Kalinin & 15 & 151 & 29 & 20 \\
\hline Novovoronezh & 11 & 98 & 22 & 12 \\
\hline Total & 48 & 519 & 77 & 56 \\
\hline
\end{tabular}

\section{Results of the investigation monitoring}

The comparison to the current standards is also provided. The radiation hygienic situation in NPP surveillance areas is generally satisfactory and stable:

- Outdoors gamma dose rate is in the range of background fluctuations for such territories;

- $\quad{ }^{90} \mathrm{Sr}$ and ${ }^{137} \mathrm{Cs}$ specific activity in outdoor water reservoirs is in the range of radionuclide content in water reservoirs of the Central Russia;

- $\quad{ }^{90} \mathrm{Sr}$ and ${ }^{137} \mathrm{Cs}$ burdens in drinking water is below intervention levels for 135 and almost 300 times, respectively; total alpha and beta activity is below permissible levels;

- ${ }^{90} \mathrm{Sr}$ and ${ }^{137} \mathrm{Cs}$ burdens in foodstuff products and drinking water are 1001000 times below permissible levels;

- ${ }^{90} \mathrm{Sr}$ and ${ }^{137} \mathrm{Cs}$ burdens in foodstuff products and drinking water (NPP surveillance areas) are similar to these in other regions of the country.

Table 3 provides total doses in NPP vicinity residents due to all sources of ionizing radiation. As it follows from Table 3, the natural background irradiation 
results to $69-71 \%$ of total effective dose from all sources. The dose impact of global fallout and NPP exposure is $0.2-0.3 \%$ in the vicinity of Volgodonsk, Kalinin and Novovoronezh NPPs [4].

The assessment of the health baseline in the vicinity of NPPs as well as in the comparison areas was elaborated within more than ten years. The peculiar attention was attracted to the malignant neoplasm morbidity, its incidence rate and dynamics. Specifying children health and the morbidity structure is estimated. Data obtained did not show any significant terms of worse health state of adults and children.

At present time, the radiation hygienic monitoring in the NPP vicinity can provide the radiation risk assessment (Table 4). The individual population risk for all radiation sources in surveillance areas of three examined NPPs is (2.5$3.1) \cdot 10^{-4}$ cases per year. The individual risk related to the NPP operation is $0.4 \cdot 10^{-12}$ (Volgodonsk NPP) to $3.2 \cdot 10^{-8}$ (Novovoronezh NPP) cases per year. Thus, this risk is hundreds and even million times lower if compared to unconditional acceptable risk (UAR) $-1 \cdot 10^{-6}$.

Table 3: Total effective doses in the population in the NPP vicinity, $\mathrm{mSv} /$ year.

\begin{tabular}{|c|c|c|c|c|}
\hline $\begin{array}{c}\text { Component of } \\
\text { dose, } \mathrm{mSv} / \mathrm{y}\end{array}$ & $\begin{array}{c}\text { Volgodonsk } \\
\text { NPP }\end{array}$ & $\begin{array}{c}\text { Kalinin } \\
\text { NPP }\end{array}$ & $\begin{array}{c}\text { Novovoro- } \\
\text { nezh NPP }\end{array}$ & $\begin{array}{c}\text { Assessment } \\
\text { criteria }\end{array}$ \\
\hline $\begin{array}{c}{ }^{137} \mathrm{Cs} \text { and }{ }^{90} \mathrm{Sr} \\
\text { man-caused } \\
\text { background }\end{array}$ & 0,007 & 0,0079 & 0,010 & $\begin{array}{c}\text { Russia }-0.022 \\
\text { world }-0.007\end{array}$ \\
\hline NPP & 0,0000006 & 0,00044 & 0,0017 & 0.01 \\
\hline $\begin{array}{c}\text { Natural } \\
\text { sources }\end{array}$ & 2,4 & 2,9 & 2,3 & 2.4 \\
\hline $\begin{array}{c}\text { Medical } \\
\text { sources }\end{array}$ & 1,0 & 1,3 & 1,2 & $\begin{array}{c}\text { Russia }-1.0 \\
\text { world }-0.4\end{array}$ \\
\hline $\begin{array}{c}\text { Sum of all } \\
\text { sources }\end{array}$ & 3,4 & 4,2 & 3,5 & $\begin{array}{c}\text { Russia }-3.5 \\
\text { world }-2.8\end{array}$ \\
\hline
\end{tabular}

Table 4: Individual life span risk of stochastic effects in residents of the NPP surveillance area, year ${ }^{-1}$.

\begin{tabular}{|c|c|c|}
\hline $\begin{array}{c}\text { Risk due to all the } \\
\text { sources }\end{array}$ & $\begin{array}{c}\text { Risk due to NPP } \\
\text { operation }\end{array}$ & $\begin{array}{c}\text { Unconditional } \\
\text { Acceptable Risk/ } \\
\text { Risk due to NPP } \\
\text { operation }\end{array}$ \\
\hline \multicolumn{3}{|c|}{ Volgodonsk NPP } \\
\hline $2,5 \cdot 10^{-4}$ & $4,0 \cdot 10^{-13}$ & 2,5 million times \\
\hline $3,1 \cdot 10^{-4}$ & Kalinin NPP & 150 times \\
\hline & $6,6 \cdot 10^{-9}$ & 30 times \\
\hline
\end{tabular}




\section{Conclusion}

The developed comprehensive investigation monitoring in the NPP vicinity (a) should be the necessary part of the nationwide system of social hygienic monitoring, (b) provides the opportunity to get the modern objective assessment of the NPP impact in the environment and population health, and (c) can be widespread to other radiation facilities in this country.

\section{References}

[1] The Russian Government Decree no. 426 from 01 June 2000 “On social hygienic monitoring".

[2] Shandala N, Petuhova E, Novikova N. et al. Monitoring of radiation-hygiene situation in areas of disposition of nuclear power plants // IRPA 11 Abstracts. $11^{\text {th }}$ International Congress on the International Radiation Protection Association, 23-28 May 2004, Madrid. Spain. - 2004. - P. 259 260.

[3] Ilyin L, Shandala N, Savkin M ea. Place and role of sanitary hygienic monitoring in the system of social and hygienic monitoring // Hygiene and sanitary, 2004. - No 5. - p. 9-15.

[4] Ilyin L, Shandala N, Kiselev M et al. Comprehensive Research Monitoring of Environment and Public Health in Regions of the Russian NPP // International conference on radioecology and environmental radioactivity, Bergen, Norway, 15-20 June 2008 - P. 310-312. 